\title{
Evaluación de una intervención con conductores designados para prevenir los accidentes de tráfico provocados por el alcohol en las discotecas de Milán, Italia
}

\section{Evaluation of a designated driver intervention to prevent alcohol-related road accidents in the clubs of Milan, Italy}

\author{
Giovanni Aresi; Luca Fornari; Chiara Repetto; \\ MARTA SCOLARI
}

| Asociación Ala Milano Onlus - Primaepoi.it project

Enviar correspondencia a:

Giovanni Aresi, via Boifava 60/a 20142 Milano, Italia. E-mail: g.aresi@alainrete.org

\section{RESUMEN}

Objetivo. El presente estudio es una evaluación de una intervención con conductores designados (CD). Los objetivos eran: (1) verificar la base de la intervención, que es dar incentivos vinculados a un resultado positivo en la prueba de alcoholemia $(<0.5 \mathrm{~g} / /)$ al salir de la discoteca, lo cual redunda en un descenso en el porcentaje de conductores que salian de la discoteca con una CAS superior al límite; (2) comprender las razones de los conductores para participar en la intervención y valorar si la operación fue efectiva para rebajar la cantidad de alcohol consumido durante la noche; (3) comprobar si hay parcialidad en la selección de conductores designados. Método. Diseño de investigación pre-experimental con un grupo de control y sin pre-test. Las dos condiciones de la variable independiente fueron: presencia o ausencia de la intervención del "Conductor Seguro». Se comparó a un grupo de conductores que participaron en la intervención ( $C D N=124)$ con un grupo que no participó (no-CD N=139). Resultados. (1) La CAS media de los $C D$ fue significativamente más baja que la de los no- $C D$, pero (2) el incentivo hizo que el 5\% de los CD bebiesen menos, y (3) hay parcialidad en la selección de $C D$ que presentan un perfil de riesgo de consumo de alcohol más bajo que los no-CD. Discusión. La eficacia de la intervención no se basa en pruebas contundentes. El incentivo de la entrada gratis no es eficaz para motivar a los conductores a beber menos. Se necesitan más investigaciones para evaluar la eficacia de las intervenciones con conductor designado, en las que se haya eliminado la parcialidad en la selección de conductores utilizando, por ejemplo, otros incentivos y teniendo una idea clara del perfil de riesgo de los conductores designados.

Palabras clave: alcohol, concentración de alcohol en sangre, conductor designado, conducción bajo los efectos del alcohol, evaluación. recibido: diciembre 2008 aceptado: junio 2009

\section{ABSTRACT}

Objective. The present study is an evaluation of a designated driver intervention. The objectives were: (1) to verify the intervention assumption, which is that offering incentives, linked to a positive result of the breathalyser test $(<0.5 \mathrm{~g} / \mathrm{l})$ when leaving the club, leads to a decrease in the percentage of drivers leaving the club with a BAC above the legal limit; (2) to understand the reason why drivers take part in the intervention and assess whether the operation was effective in lowering the amount of alcohol consumed during the night; (3) to verify the assumption that there is a bias in the selection of designated drivers. Method: Pre-experimental research design with a control group and no pre-test. The two conditions of the independent variable were: presence or absence of the "Safe Driver" intervention. A group of drivers who took part in the intervention (DDs $N=124)$ was compared with a group that did not (non-DDs $N=139$ ). Results. (1) DDs' mean BAC was significantly lower than non-DDs', but (2) the incentive motivated just 5\% of DDs to drink less, and (3) there is a bias in the selection of DDs that present a lower drinking risk profile than non-DDs. Discussion. The effectiveness of the intervention doesn't seem to be supported by strong evidence. The free-entrance incentive is not effective in motivating drivers to drink less. More research is needed to evaluate the effectiveness of designated driver interventions where the bias in the selection of drivers has been removed, by, for example, using other incentives and to have a clear understanding of designated drivers' risk profile.

Key words: alcohol, blood alcohol concentration (BAC), designated driver, driving under the influence (DUI), evaluation. 


\section{INTRODUCCIÓN}

E consumo de alcohol es uno de los factores que más influyen tanto en el riesgo de accidentes de tráfico como en la gravedad de sus consecuencias. Según la Organización Mundial de la Salud, en la mayoría de los países desarrollados en torno al $20 \%$ de los accidentes mortales se deben a un conductor que conduce bajo los efectos del alcohol (CBEA). Los choques provocados por el alcohol suelen producirse de noche, generalmente los fines de semana o durante el tiempo libre ${ }^{1}$. En Italia el número y la gravedad de los accidentes de tráfico de noche y durante los fines de semana aumenta muchísimo ${ }^{2}$. Estos accidentes casi siempre afectan a los jóvenes, que son quienes más frecuentan las discotecas. El proyecto asistencial "PrimaEpoi.it", ejecutado por la Asociación Ala Milano Onlus, funciona en las discotecas de la ciudad de Milán y contribuye a prevenir los daños derivados del consumo de alcohol y sustancias psicoactivas. En el contexto específico de las discotecas de Milán se llevó a cabo, como parte del proyecto, un estudio del comportamiento de los conductores que habían consumido alcohol y de sus percepciones. El estudio muestra que la mayoría de los clientes de las discotecas utilizan el coche a la ida y a la vuelta y que el $46 \%$ de los conductores presentan una concentración de alcohol en sangre (CAS) superior al límite legal $\left(0,5\right.$ gramos de alcohol por litro de sangre en Italia) ${ }^{3}$. Visto esto, se consideró útil centrar las intervenciones en este grupo con el fin de prevenir los accidentes de tráfico provocados por el alcohol. En los últimos años la intervención del conductor designado se ha extendido ampliamente en Italia, pero no se ha publicado ningún estudio de evaluación. Por ello, los miembros del proyecto Primaepoi.it decidieron diseñar, poner en práctica y evaluar una intervención con conductor designado denominada "Conductor Seguro".

\section{Antecedentes}

La literatura sobre la evaluación de este tema abarca unos cuantos estudios publicados entre 1994 y $1999^{4}$. Hay dos enfoques para fomentar la figura del conductor designado (CD): uno se basa en campañas de concienciación dirigidas a la población general a través de los medios, y el otro, similar al proyecto "Conductor Seguro", utiliza programas que ofrecen varios incentivos (bebidas no alcohólicas, comida o entradas gratis) en los establecimientos. En el segundo enfoque se informa al público de los incentivos a través de folletos y pósters, personal de barra y de puerta de los establecimientos, y anuncios en periódicos y televisión. Dos efectos positivos de este enfoque son: (i) un descenso del $6,5 \%$ en el número de clientes de bares que reconocieron haber conducido o viajado en compañía de un conductor con una CAS $>0.5 \mathrm{~g} / \mathrm{l}$ en las cuatro semanas anteriores ${ }^{5}$; $y$ (ii) un creciente número de personas que se describen como $\mathrm{CD}^{6,7}$. Según el Harvard Alcohol Project los beneficios de los programas de conductores designados son que promueven las normas sociales de abstinencia de consumo de alcohol, ofrecen una forma concreta y práctica de evitar la CBEA, y fomentan un comportamiento proactivo en el autocontrol de la ingesta de alcohol ${ }^{8}$. Ditter et al. observan ciertos aspec-

\section{INTRODUCTION}

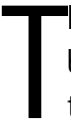
he consumption of alcohol is a major factor influencing both the risk of road accidents and the gravity of their consequences. According to the World Health Organization, in the majority of developed countries around $20 \%$ of fatal accidents involve at least one driver driving under the influence of alcohol (DUI). Alcohol-related crashes often occur at night and generally at weekends or during free time. ${ }^{1}$ In Italy, the number and gravity of car accidents occurring at night and during weekends increases dramatically. ${ }^{2}$ Moreover, these accidents frequently involve young people, who are more likely to go clubbing. The outreach project "PrimaEpoi.it", implemented by the association Ala Milano Onlus, works inside clubs in the city of Milan. It aims to prevent damage resulting from the consumption of alcohol and psychoactive substances. Within the specific context of Milan clubs, a survey on drink-driving behavior of drivers and on their perceptions was carried out as part of this project. It shows that the majority of the club-goers use the car to reach and leave the club and that $46 \%$ of the drivers present a blood alcohol concentration (BAC) over the legal limit ( 0.5 grams of alcohol per liter of blood in Italy). ${ }^{3}$ It was then considered useful to focus the implementation of interventions on this target group with the aim of preventing alcohol-related road accidents. In past years designated driver intervention has been widely implemented in Italy, but no evaluation study has been published. For this reason the staff of the Primaepoi.it project decided to design, implement and evaluate a designated driver intervention called "Safe Driver".

\section{Background}

Literature on the evaluation of this subject comprises a few studies published between 1994 and 1999. ${ }^{4}$ There are two approaches used to promote the identification of a designated driver (DD): one is based on awareness campaigns targeting the general population through the media, while the other, similar to the "Safe driver" project, employs programs that offer various incentives (non alcoholic beverages, food or free entrances) in drinking establishments. In the latter approach, the public is informed of the availability of the incentives through flyers and posters, bar tenders and door staff, and newspaper or television advertisements. Two positive effects demonstrated by this approach are: (i) a $6.5 \%$ decrease in the number of bar-goers who reported driving, or traveling with a driver, with a BAC $>0.5 \mathrm{~g} / \mathrm{l}$ in the previous four weeks, ${ }^{5}$ and (ii) an increasing number of people describing themselves as DDs. ${ }^{6,7}$ According to the Harvard Alcohol Project the benefits of the designated driver programs are that they promote the social norm of abstinence from alcohol consumption, offer a specific and practical way to avoid DUI and encourage proactive behavior as regards self-monitoring alcohol intake. ${ }^{8}$ Ditter et al. report some possible negative aspects: the 
tos negativos: el número de conductores que se autodefinen como $C D$ retoman sus costumbres en cuanto se retiran los incentivos, y existen discrepancias entre el CD ideal y la conducta real ${ }^{4}$. En un estudio de la CAS media de los CD rondó $0,6 \mathrm{~g} / \mathrm{l} .{ }^{9}$ Por ultimo, aparte de las limitaciones de los datos que ofrecen los propios interesados sobre la frecuencia de CBEA, la pregunta sin respuesta es: ¿Cómo se habrian comportado los CD sin la intervención? ¿Se habrían comportado igual de "bien" o habrian utilizado estrategias alternativas para evitar la CBEA?

\section{El proyecto Conductor Seguro}

El proyecto "Conductor Seguro" pretende prevenir los accidentes de tráfico provocados por el alcohol en las discotecas de Milán por medio de intervenciones con conductores designados. El objetivo concreto del proyecto es que disminuya el número de conductores que salen de las discotecas con una CAS superior al límite legal. La intervención se ha centrado en los clientes de discotecas que conducen. Se parte de la base de que los conductores con una CAS superior al límite legal tienen mayor riesgo de sufrir accidentes de tráfico. La intervención parte del supuesto de que los incentivos vinculados a la prueba de alcoholemia $(<0.5 \mathrm{~g} / \mathrm{l})$ al salir de la discoteca disminuyen el porcentaje de conductores con una CAS superior al límite legal. El incentivo es una entrada gratis el mes siguiente. La intervención fue realizada por profesionales con conocimientos especializados en prevenir la conducción bajo los efectos del alcohol. Los miembros de la intervención se dirigieron a grupos de clientes y les pidieron que identificasen al conductor. Una vez identificado, se le informó de la operación. La participación fue voluntaria y gratuita. A los conductores que aceptaron se les hizo la prueba de alcoholemia y se les dio una pulsera. Se contó el número de conductores que se negaron a participar $y$, cuando fue posible, se hizo constar el motivo de su negativa. Antes de marcharse, los conductores se reunieron con los miembros de la intervención y cubrieron un cuestionario autoadministrado antes de someterse a la prueba de alcoholemia. Si la CAS del conductor estaba dentro del límite legal, se le regalaba una entrada gratis. En caso contrario, se advertía al conductor que no condujese y se debatían con él estrategias alternativas a la CBEA (p.ej., que condujese un amigo, coger un taxi o un autobús, esperar que disminuyese la CAS, etc.) El personal de campo de la intervención permaneció en la discoteca hasta que se marcharon todos los clientes.

\section{Objetivo}

El presente estudio es una evaluación de la intervención "Conductor Seguro". (1) Objetivo 1: verificar la base de la intervención, que es dar incentivos vinculados a un resultado positivo en la prueba de alcoholemia $(<0,5 \mathrm{~g} / \mathrm{l}$.) al salir de la discoteca, lo cual redunda en un descenso del porcentaje de conductores que salen de la discoteca con una CAS superior al límite legal. Se espera que los conductores que participen en la operación "Conductor Seguro" tengan una CAS inferior a los que no participen e inferior asimismo al límite number of self-identified DDs seems to return to the baseline immediately after withdrawing the enhanced incentives and often a discrepancy exists between the ideal DD and actual behavior. ${ }^{4}$ In a study the mean DDs' BAC was around 0.6 $\mathrm{g} / \mathrm{I} .{ }^{9}$ Finally, beyond the limitations of self-report data of the frequency of DUI, the unanswered question is: how would the DDs have behaved without the intervention? Is it possible that these drivers would have behaved as "good" DDs anyway, or might they have used alternative strategies to avoid DUI?

\section{The Safe Driver project}

The "Safe Driver" project aims to prevent alcohol-related road accidents in the clubs of Milan by using designated driver interventions. The specific project purpose is to decrease the number of drivers leaving clubs with a BAC above the legal limit. The intervention is aimed at nightclub patrons who drive. The causal assumption is that drivers with a BAC above the legal limit are those who have a higher risk of getting involved in a road accident. The intervention assumption is that offering incentives, linked to a breathalyzer test $(<0.5 \mathrm{~g} / \mathrm{l})$ when leaving the club, should decrease the percentage of drivers leaving the club with a BAC above the legal limit. The incentive is free entrance to the club for one night during the following month. The intervention was carried out by professional field staff with specific knowledge of drink-driving prevention. The staff intercepted groups of patrons and asked them to identify the driver. Once identified, the driver was informed about the operation. The participation was voluntary and free of charge. The drivers who accepted were breathanalyzed and given a bracelet to wear. The number of drivers who refused to take part was counted and, if possible, the reason of their refusal was recorded. Before leaving, the drivers went back to the staff and completed a self-administered questionnaire before being breathanalayzed. If the driver's BAC was within the legal limit, free entrance was given. If not, the driver was advised not to drive and alternative strategies to DUI were discussed (i.e. letting a friend drive, taking a taxi or a bus, waiting for the BAC to decrease, etc.). The field staff stayed in the club until all the patrons had left.

\section{Objective}

The present study is an evaluation of the "Safe Driver" intervention. (1) Objective 1: to verify the intervention assumption, which is that offering incentives, linked to a positive result of the breathalyzer test $(<0.5 \mathrm{~g} / \mathrm{l})$ when leaving the club, leads to a decrease in the percentage of drivers leaving the club with a BAC above the legal limit. It is expected that drivers participating in the "Safe driver" operation would have lower BAC than those not participating and would have a BAC below the legal limit. As part of this 
legal. Como parte del objetivo, también se tendrá en cuenta la influencia del género y la edad de los conductores en la CAS; (2) objetivo 2: identificar el motivo de los conductores para participar en la intervención y valorar si la operación ha logrado rebajar la cantidad de alcohol consumido durante la noche; (3) objetivo 3: verificar el supuesto, basado en experiencias previas, de que los conductores que participan en la operación y aceptan someterse a la prueba de alcoholemia presentan generalmente un perfil de riesgo de CBEA inferior a la población global de clientes de discotecas que vuelven a casa conduciendo.

\section{MÉTODO}

El presente estudio se basa en un método de investigación pre-experimental con un grupo de control y sin pre-test ${ }^{10}$. Las dos condiciones de la variable independiente fueron la presencia o ausencia de la intervención del "Conductor Seguro". Para evitar otras variables, sólo se incluyeron las discotecas principales de Milán (abiertas al público general) de una lista de posibles centros de intervención. Se eligieron cuatro discotecas al azar. El grupo experimental (CD) se formó con los conductores que aceptaron participar en la intervención y someterse a la prueba de alcoholemia tras cubrir un cuestionario a la salida de la discoteca. Se pidió a los conductores que cubriesen el cuestionario en el momento de salir de la discoteca. El grupo de control (grupo de no-CD) estaba formado por una muestra de conductores que salian de la discoteca una semana después sin ninguna intervención. (1) La comparación de estos dos grupos contempló la CAS media y el porcentaje de conductores con una CAS $>0.5$ $\mathrm{g} / \mathrm{l}$ en el momento de abandonar la discoteca (objetivo 1); (2) para evaluar el impacto de la intervención (objetivo 2), en el caso del grupo de CD se recogió información sobre el número de conductores que habian reducido su consumo de alcohol tras la intervención y los motivos para participar en ella; (3) Asimismo, se compararon las pautas de consumo de alcohol del último mes (UM), el número veces que el cliente se habia emborrachado o había CBEA (objetivo 3). Para el análisis estadístico se utilizó el programa SPSS (13.0).

\section{Participantes y selección}

El número total de conductores abordados fue de 405. La tasa de rechazo fue del 9,1\% $(n=37)$. En el grupo de control (grupo de no-CD) habia 139 conductores, en el grupo experimental (grupo CD) 124, y 105 conductores seleccionados al principio de la noche no se presentaron a la prueba de alcoholemia ni cubrieron el cuestionario al salir de la discoteca. Estos 105 conductores no se incluyeron en ese grupo. El $79,1 \%(n=208)$ de participantes eran hombres y la edad media de 24,6 años. El rango de edad abarcaba desde 17 hasta 45 años. No hubo asociaciones significativas en términos de género $\left(\chi^{2}\right.$ (d.f. 1$\left.)=.004 p>0,5\right)$ ni diferencias significativas en términos de edad (t-test $=1,585 p>0,5$ ) entre los dos grupos. Por tanto, se trataba de grupos homogéneos en lo relativo a estas variables. La mayoria de los participantes eran trabajadores $(63,9 \% ; n=168)$ o estudiantes $(32,7 \%$; objective, the influence of drivers' gender and age on their BAC will also be considered; (2) objective 2: to understand why drivers take part in the intervention and assess whether the operation was effective in lowering the amount of alcohol drunk during the night; (3) objective 3 : to verify the assumption, based on previous experience, that drivers who take part in the operation and accept to be breathalyzed generally present a profile of people with a lower DUI risk than that of the general population of club-goers who drive home.

\section{METHOD}

The present study was based on a pre-experimental research method with a control group and no pre-test. ${ }^{10}$ The two conditions of the independent variable were the presence or absence of the "Safe Driver" intervention. In order to avoid further variables, only mainstream clubs (for the general public) in the city of Milan were included in a list of possible intervention sites. Four clubs were randomly chosen. The experimental group (DD group) comprised those drivers who accepted to take part in the intervention and to be breathalyzed after completing a questionnaire at the exit of the club. The drivers were asked to complete the questionnaire just before leaving the club. The control group (non-DD group) comprised a sample of drivers leaving the same club a week later without any intervention. (1) The comparison of these two groups concerned the mean BAC and the percentage of drivers with a $>0.5 \mathrm{~g} / \mathrm{BAC}$ at the time of leaving the club (objective 1); (2) in order to evaluate the impact of the intervention (objective 2), for the DD group only, information was collected regarding the number of drivers who reduced their consumption of alcohol due to the intervention and why they took part in it; (3) the last month (LM) drinking behavior and the number of times patrons got drunk and DUI reports were also compared between the two groups (objective 3 ). SPSS (13.0) was used for the statistical analysis.

\section{Participants and recruitment}

The total number of drivers approached was 405 . The refusal rate was $9.1 \%(\mathrm{~N}=37)$. The control group (non-DD group) comprised 139 drivers, the experimental group (DD group) comprised 124 drivers, and 105 recruited drivers at the beginning of the evening did not come back to be breathalyzed and to complete the questionnaire on leaving the club. Those 105 drivers were not included in that group. $79.1 \%(N=208)$ of participants were male and the mean age was 24.6. Their age range was between 17 and 45. No significant association in terms of gender ( $\chi^{2}$ (d.f. 1) $=.004 p>0,5)$ and no significant difference in terms of age (t-test $=1,585 p>0,5)$ were found between the two groups. So the groups proved to be homogenous in relation to these variables. Most of the participants were workers 
$n=86)$, mientras que el $10,6 \%(n=28)$ compaginaban estudios y trabajo, y el $2,7 \%(n=7)$ estaban parados. El $19,8 \%$ $(n=52)$ de los participantes tenían la enseñanza general básica, el $57,8 \%(n=152)$ el bachillerato, y el $22,1 \%(n=58)$ una carrera universitaria. Como hemos explicado antes, los miembros de la intervención abordaron aleatoriamente a los clientes a la puerta de la discoteca y les explicaron el programa "Conductor Seguro». En el caso del grupo de no-CD, los encuestadores abordaron a grupos de personas que salian de la discoteca y les explicaron que estaban realizando un estudio sobre los hábitos de consumo de alcohol de los clientes de las discotecas. Como incentivo se dio un obsequio a los conductores que aceptaron cubrir el cuestionario y someterse al alcoholímetro. En ambos casos el único criterio de selección fue el de ser conductor. La selección se realizó en junio y julio de 2008.

\section{Cuestionario y valoración de la CAS}

Los niveles de CAS de los participantes se midieron con un alcoholimetro portátil profesional SD-400 (Lion Laboratories Ltd, Gran Bretaña) que ofrece la CAS (con dos dígitos decimales) en gramos de alcohol por litro de sangre. Los grupos de $C D$ y no-CD cubrieron el mismo cuestionario. Se recogió información sobre: (i) datos demográficos, (ii) frecuencia de consumo de alcohol el mes anterior (escala ordinal con 5 categorías), si el mes anterior se emborracharon (iii) y con qué frencuencia, o (iv) si condujeron alguna vez bajo los efectos del alcohol (y, en caso afirmativo, con qué frecuencia). El grupo de CD cubrió una sección adicional del cuestionario en la que se preguntaba por qué participaban en la operación "Conductor Seguro" y si habian modificado su consumo de alcohol a partir de entonces.

\section{RESULTADOS}

\section{Objetivo 1}

A partir de la CAS de los conductores se realizó un análisis de varianza (ANOVA) 2 género $\times 2$ tipo de conductor (CD vs. no-CD) con la edad como covariable. Como se ve en la tabla 1, el ANOVA detectó el efecto más significativo por tipo de conductor, no por género ni por edad. El resultado del ANOVA no fue significativo en la interacción género $x$ conductor. La varianza obtenida por el modelo fue del 13\%. La CAS media de los conductores del grupo CD fue mucho más
(63.9\%; $N=168)$ or students $(32.7 \% ; N=86)$, while $10.6 \%$ $(\mathrm{N}=28)$ were studying and working at the same time, and finally $2.7 \%(\mathrm{~N}=7)$ were unemployed. $19.8 \%(\mathrm{~N}=52)$ of participants had a middle school level of education, $57.8 \%$ $(\mathrm{N}=152)$ a high school education and $22.1 \%(\mathrm{~N}=58)$ had a degree. As described above, the staff randomly approached customers entering the club and explained the "Safe driver" event to them. Similarly, for the non-DD group, the staff approached groups of people leaving the club indicating that they were conducting a study on club customers' drinking behavior. As an incentive, a gadget was given to those drivers who agreed to complete a questionnaire and to be breathalysed. In both cases no selection criteria other than being a driver were applied. The recruitment was performed during June and July 2008.

\section{Questionnaire and BAC assessment}

Participants' BAC levels were assessed using a professional hand-held SD-400 breathalyzer (Lion Laboratories Ltd, UK) which offers the BAC (two decimal digits) in grams of alcohol per liter of blood. The same questionnaire was completed by DD and non-DD groups. It collected information about: (i) demographic data, (ii) last month drinking frequency (5 step ordinal scale), whether during the previous month they (iii) ever got drunk (and how often) or (iv) ever drove under the influence of alcohol (and, if so, how often). The DD group completed an additional debriefing section in which they were asked why they took part in the "Safe driver" operation and whether they modified their alcohol consumption because of this.

\section{RESULTS}

\section{Objective 1}

A 2 Gender x 2 Driver type (DD vs. non-DDs) analysis of variance (ANOVA) with age as a covariate was calculated on drivers' BAC. As depicted in table 1, the ANOVA resulted in significant main effect for Driver Type, but not for Gender and age. The ANOVA result was not significant for Gender $x$ Driver type interaction. The variance explained by the model was $13 \%$. The mean drivers' BAC of the DD group was significantly

Tabla 1. ANOVA de Concentración de Alcohol en Sangre (CAS).

Table 1: ANOVA for BAC.

\begin{tabular}{|c|c|c|c|c|}
\hline Fuente / Source & g.l. / df & MS & $\mathrm{F}$ & $\begin{array}{l}\text { Significación } \\
\text { Significance }\end{array}$ \\
\hline Edad / Age & 1 & .209 & .893 & $p=.346$ \\
\hline Género / Gender & 1 & .751 & 3.202 & $p=.75$ \\
\hline Tipo de conductor / Driver type & 1 & 2.301 & 9.840 & $\mathrm{p}<.05$ \\
\hline Género $x$ tipo de conductor / Gender X Driver type & 1 & .15 & .64 & $\mathrm{p}=.800$ \\
\hline Error / Error & 252 & .235 & & \\
\hline
\end{tabular}


Tabla 2. Concentración de alcohol en sangre (CAS) de conductores por encima del límite legal. Comparación entre el grupo CD y el no CD. Table 2: Drivers' BAC above legal limit comparison between DD and non-DD groups.

\begin{tabular}{lcccc}
\hline Variable & Grupo CD / DD group & Grupo no-CD / Non-DD group & Análisis / Analysis & Significación / Significance \\
\hline CAS de conductores / Drivers'BAC & Si / Yes & $22,8 \%(\mathrm{~N}=28)$ & $46 \%(\mathrm{~N}=63)$ & $\chi^{2}(\mathrm{~g} . \mathrm{l}=1)$ \\
Por encima del limite legal de 0,5g/l / above legal limit 0,5g/l & No / No & $77,2 \%(\mathrm{~N}=95)$ & $54 \%(\mathrm{~N}=74)$ & 15.362 \\
\hline
\end{tabular}

baja que la del grupo no-CD. Los no CD (CAS media $=0.53$ $\mathrm{g} / \mathrm{I})$ se embriagaron más que los CD (CAS media $=0.31 \mathrm{~g} / \mathrm{l}$ ).

Por otro lado, como se ve en la tabla 2 , un análisis $\chi^{2}$ demostró que los CD se asociaban de forma significativa con una CAS inferior al límite legal para conducir.

\section{Objetivo 2}

El 59,7\% ( $n=74)$ de los CD afirmaron que participaban en la operación "Conductor Seguro" porque les interesaba conocer su CAS. Otras razones fueron: el incentivo de la entrada gratuita $(17,7 \% ; n=22)$, la seguridad de conseguir el incentivo porque pensaban beber poco $(16,9 \%, n=21)$, la responsabilidad de llevar pasajeros en el coche $(12,1 \% ; n=15)$, el miedo a las multas y a los accidentes de tráfico $(12,1 \% ; n=15)$, y por último la sensación de desafío $(10,5 \% ; n=13)$.

La figura 1 describe la modificación de los hábitos de consumo de alcohol de los CD durante la noche. La mayoría de los CD (casi 3 de cada 4) afirmó que habian bebido lo mismo que siempre. De los que bebieron menos $(n=28)$, sólo 6 ( $5 \%$ del total de $C D$ ) admitieron que la entrada gratis había sido el motivo principal para participar en el programa. La intervención tuvo el mismo impacto entre los CD hombres y mujeres. No hubo diferencias entre grupos ya que casi la misma proporción afirmaron que habian bebido lo mismo que siempre o más: $74,7 \%$ de los hombres $(n=208)$ y $72 \%$ $(n=52)$ de las mujeres $\left(\chi^{2}(g . l=1)=.79, p>.05\right)$. La comparación por grupo de edad arrojó resultados similares: $66,7 \%$ $(n=16)$ del grupo de los de 20 años o menos; 77,3\% $(n=17)$ del grupo entre 21 y 23 años; 74,5\% $(n=35)$ del grupo entre 24 y 27 años; y 71\% $(n=22)$ del grupo de más de 28 años afirmaron que no habian reducido su consumo de alcohol $\left(\chi^{2}\right.$ $(g . l .=3)=.961, p>.05)$. lower than the non-DD group. Non-DDs (Mean BAC $=0.53 \mathrm{~g} / \mathrm{l}$ ) were more intoxicated than DDs (Mean $B A C=0.31 \mathrm{~g} / \mathrm{l}$ ).

In addition, as can be seen in table 2 , a $\chi^{2}$ analysis indicated that being a DD was significantly associated with a BAC below the legal driving limit.

\section{Objective 2}

$59.7 \%(N=74)$ of DDs reported that they took part in the "Safe driver" operation because they were interested in having their BAC assessed. Other reasons were: the free entrance incentive $(17.7 \% ; N=22)$, the fact that they were sure to win the incentive because they expected not to drink much $(16.9 \%, N=21)$, the responsibility of having passengers to take home $(12.1 \% ; N=15)$, the fear of getting fines and having car accidents $(12.1 \% ; \mathrm{N}=15)$ and, finally, a sense of challenge $(10.5 \% ; \mathrm{N}=13)$.

Figure 1 describes the modification of DDs' drinking behavior during the night. Most of DDs (almost 3 out of 4) reported that they drank as much as usual. Of those who drank less $(\mathrm{N}=28)$, just $6(5 \%$ of total DDs) gave the free entrance incentive as the main reason why they took part in the event. The intervention had the same impact on male and female DDs. There was no difference between groups since nearly the same proportion reported that they drank as much as usual or more: $74.7 \%$ of male $(\mathrm{N}=208)$ and $72 \%(N=52)$ of female $\left(\chi^{2}(\right.$ d.f. 1$\left.)=.79, p>.05\right)$. The comparison by age group led to similar findings: $66.7 \%(\mathrm{~N}=16)$ of the 20 years-old or less group, $77.3 \%(\mathrm{~N}=17)$ of 21 - to 23-year-old group, $74.5 \%(\mathrm{~N}=35)$ of 24 - to 27 -year-old group and $71 \%(\mathrm{~N}=22)$ of the over 28 group reported that they hadn't reduced their alcohol consumption ( $\chi^{2}$ (d.f. 3$)=$ $.961, p>.05)$.

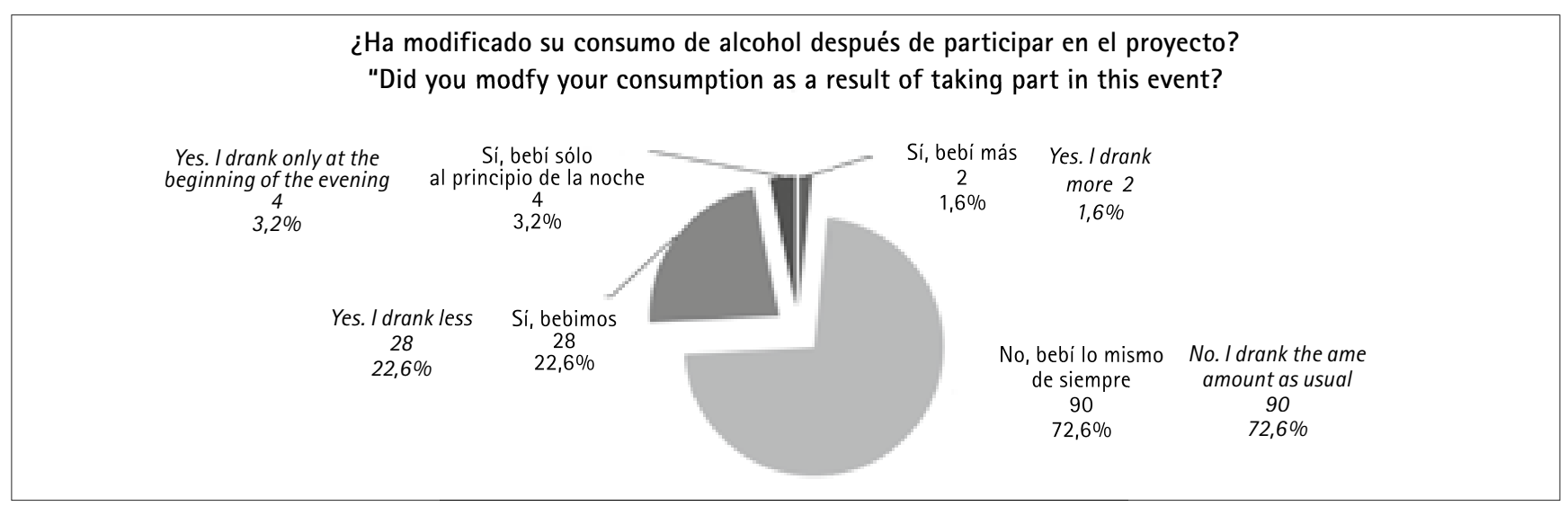

Figura 1: Consumo de alcohol de los CD / Figure 1: DDs drinking behavior 


\section{Objetivo 3}

Se comparó el grupo CD con el grupo no-CD para comprobar la hipótesis de que los participantes en la operación presentan un perfil de riesgo de CBEA más bajo que la población general de clientes de discotecas cuando regresan a casa en coche. Los resultados fueron (Tabla 3): (1) Los no $C D$ declararon beber bastante más a menudo que los $C D$; (2) los no $C D$ admitieron al menos un episodio de CBEA más a menudo que los $C D$, pero la asociación no fue significativa; (3) los no CD condujeron bajo los efectos del alcohol con mayor frecuencia que los $C D$ aunque la diferencia no sea estadisticamente significativa; (4) el reconocimiento de al menos un episodio de embriaguez en el mes anterior se asoció significativamente con los no $C D$; y (5) los no $C D$ se embriagaron con mayor frecuencia que los $C D$ durante el mes anterior. Puesto que los grupos eran homogéneos en términos de edad y género, con toda probabilidad estas variables no afectaron al perfil de riesgo de los conductores.

\section{DISCUSIÓN}

Los resultados demuestran que, en comparación con el grupo de control (no-CD), la CAS de los CD fue significativamente más baja y más a menudo inferior al límite legal. Timmermann et al. observaron que las mujeres se embriagaban más que los hombres ${ }^{9}$. En este estudio el género no influyó en la CAS de los conductores y tampoco la edad (objetivo 1). La consideración de estos datos aislados sugiere que una intervención con conductores designados modera de forma efectiva el consumo de alcohol de los clientes de las discotecas, reduciendo por consiguiente el riesgo de accidentes del tráfico provocados por el alcohol. Sin embargo, otros resultados de esta investigación indican que semejante razonamiento podría estar sesgado. Los CD y los no-CD se diferencian en ciertos aspectos importantes (objetivo 3). La respuesta positiva a la pregunta sobre un episodio de CBEA

\section{Objective 3}

The DD group and non-DD group were compared to verify the assumption that those who take part in the operation present a lower DUI risk profile than the general population of club customers who drive home. The results were (see table 3): (1) non-DDs reported that they drank significantly more often than DDs; (2) non-DDs reported at least one DUI episode more often than DDs but the association was not significant; (3) non-DDs drove under the influence of alcohol with a higher frequency than DDs even though the difference was not statistically significant; (4) reporting at least one drunken episode in the previous month was significantly associated with being a non-DD; and (5) non-DDs got drunk significantly more frequently than DDs during the previous month. Since the groups were homogeneous in terms of age and gender, these variables most likely did not affect drivers' risk profile.

\section{DISCUSSION}

Findings showed that compared with the control group (non-DDs), the mean BAC of DDs was significantly lower and more often below the legal limit. Timmermann et al. found that women were more intoxicated than men. ${ }^{9}$ In this study gender, and also age, had no influence on drivers' BAC (objective 1). This data, if considered alone, suggests that a designated driver intervention effectively motivates club customers to moderate their consumption of alcohol, thus reducing the risk of alcohol-related road accidents. However, other results of this research suggest that this reasoning may be biased. DDs and non-DDs seem to differ in some important aspects (objective 3). The positive response to the question of having a DUI episode at least once in the last month were similar for DDs non-DDs. However non-DDs reported a higher number of DUI episodes: although not statistically

Tabla 3: Comparación entre los grupos de CD y no-CD para determinar un perfil de riesgo.

Table 3: Comparison between DD and non-DD groups to determine a risk profile.

\begin{tabular}{|c|c|c|c|c|c|}
\hline Variable & & Grupo CD / DD group & Grupo no-CD / Non-DD group & Análisis / Analysis & Significación / Significance \\
\hline \multirow{5}{*}{$\begin{array}{l}\text { (1) Frecuencia consumo alcohol, ultimo mes / } \\
\text { (1) LM drinking frequency }\end{array}$} & Nunca / Never & $10,5 \%(n=13)$ & $2,2 \%(n=3)$ & & \multirow{5}{*}{$p<.001$} \\
\hline & 1 vez o menos / Once or less & $9,7 \%(n=12)$ & $10,1 \%(n=14)$ & U de Mann-Whitney & \\
\hline & 2-3/mes / 2-3 a month & $37,9 \%(n=47)$ & $14,5 \%(n=20)$ & & \\
\hline & 1-3/semana / 1-3 a week & $29 \%(n=36)$ & $42 \%(n=58)$ & 5684.5 & \\
\hline & 4 o más / 4 or more & $12,9 \%(n=16)$ & $31,2 \%(n=53)$ & & \\
\hline (2) CBEA al menos 1 vez, ultimo mes / & Si / Yes & $29 \%(n=36)$ & $37,6 \%(n=50)$ & $\chi^{2}(g . l .=1)$ & No significativa / \\
\hline (2) LM DUl at least once & No / No & $71 \%(n=88)$ & $62,3 \%(n=83)$ & 2,113 & Not significant \\
\hline $\begin{array}{l}\text { (3) Número de CBEA UM / } \\
\text { (3) LM number of DUI }\end{array}$ & Promedio / Mean & $\begin{array}{c}0,65 \\
\text { (d.t. }=0,116)\end{array}$ & $\begin{array}{c}0.98 \\
\text { (d.t. }=0,146)\end{array}$ & $\begin{array}{l}\text { t-test } \\
-1.812\end{array}$ & $\begin{array}{l}\text { No significativo / } \\
\text { Not significant }\end{array}$ \\
\hline \multirow{2}{*}{$\begin{array}{l}\text { (4) Embriaguez al menos } 1 \text { vez, último mes / } \\
\text { (4) LM drunkenness at least once }\end{array}$} & Si / Yes & $33,9 \%(n=42)$ & $52,2 \%(n=70)$ & $\chi^{2}(g . l .=1)$ & \\
\hline & No / No & $66,1 \%(n=82)$ & $47,8 \%(n=64)$ & 8.845 & $p<.05$ \\
\hline $\begin{array}{l}\text { (5) Frecuencia de embriaguez UM / } \\
\text { (5) LM frequency of drunkeness }\end{array}$ & Promedio / Mean & $\begin{array}{c}0,81 \\
\text { (d.t. }=1.424)\end{array}$ & $\begin{array}{c}1,69 \\
\text { (s.d }=2.532)\end{array}$ & $\begin{array}{l}\text { t-test } \\
-3.442\end{array}$ & $\mathrm{p}=.001$ \\
\hline
\end{tabular}

$\mathrm{LM}=$ last month

$D V I=$ driving under the influence 
en el mes anterior fue similar entre los $C D$ y los no-CD. Sin embargo, los no-CD reconocieron un mayor número de episodios de CBEA, no significativos estadísticamente. Asimismo, bebieron con menor frecuencia durante el mes anterior y fueron menos propensos a embriagarse al menos una vez el mes anterior. Además, los no-CD se embriagaron mucho más a menudo que los $C D$. Estos resultados apoyan la idea de que los conductores que participan en la intervención son bebedores de menor riesgo, aunque no queda claro si también se hallan en menor riesgo de caer en CBEA. En contraste con otras intervenciones de reducción del daño (como los servicios de pasajeros seguros), que atrajeron a los bebedores de riesgo, los participantes en la intervención del "Conductor Seguro" presentan un perfil de riesgo menor que la población general de clientes de las discotecas que regresan a casa en coche ${ }^{11}$. Como han advertido Timmermann et al. en esta intervención se han ofrecido distintos incentivos para valorar la CAS en el grupo de control (grupo de no-CD) con el fin de no disuadir a los que consumían menos alcohol de someterse a la prueba de alcoholemia 9 . Esto confirma en cierto modo la idea de que el grupo de no-CD representa a la población esencial de clientes de discotecas de Milán, mientras que el grupo que participó en la intervención (grupo CD) representa a una subpoblación expuesta a menor riesgo.

La pregunta de Ditter: "¿Cuántas de estas personas (CD participantes en la intervención) son nuevos conductores designados elegidos por el programa, frente a los que habrian actuado como tales incluso sin el programa o habrían utilizado otros medios de transporte alternativos y seguros?", permanece sin respuesta ${ }^{4}$. Suponemos que los CD que participaron en nuestro proyecto seguramente habrian actuado como buenos conductores designados incluso sin intervención puesto que presentan un perfil de riesgo más bajo que la población general y afirmaron no haber reducido su consumo habitual de alcohol durante la prueba.

Con respecto al impacto de la intervención (objetivo 2), la oferta de entradas libres no motivó de forma especial a los clientes de las discotecas para participar en la iniciativa. La razón principal que dieron los $C D$ para participar fue la curiosidad de conocer su CAS. Esto se explica porque a la gente le resulta difícil valorar su propia CAS basándose en el consumo de alcohol de una noche determinada y de su propia percepción de la sobriedad ${ }^{3}$. Por ello les interesa contar con información basada en datos empíricos. Otro elemento fundamental fue que la mayoria de los CD afirmaron que la participación en la iniciativa no había cambiado en absoluto sus hábitos de consumo de alcohol. Esto se explica por el deseo de conocer su propia CAS, más que por un compromiso con la iniciativa y la atracción del incentivo de la entrada libre. Teniendo en cuenta la baja proporción de $\mathrm{CD}$ que bebieron menos de los habitual a causa del incentivo $(5 \%, n=6)$, parece que dicho incentivo influyó poco en el cambio de hábitos de consumo de alcohol de los conductores. Sin embargo, proporciona a los clientes de las discotecas la ocasión de conocer su CAS y puede servir para atraerlos hacia iniciativas de prevención en ese contexto. El incentivo de la entrada libre no empujó a los conductores a reducir el consumo de alcohol, al menos en el contexto concreto de significant. They also drank less often during the preceding month and also are less likely to have been drunk at least once during the preceding month. Moreover, non-DDs got drunk significantly more often than DDs. These results provide some support to the suggestion that drivers who take part in the intervention are less risk drinkers even though it is not clear if they are also at less risk for DUI. In contrast with other harm reduction interventions (such as safe riders services) that proved to attract at-risk drinkers, people who take part in the "Safe driver" intervention seem to present a lower risk profile than the general population of club customers who drive home. ${ }^{11}$ As Timmermann et al. advised, in this intervention different incentives to the BAC assessment have been offered for the control group (non-DD group) in order to reduce the risk of dissuading those who consumed less alcohol from being breathalyzed. ${ }^{9}$ This gives some support to the notion that non-DD group may indeed be representative of the target population of club customers in Milan, while the group that took part in the intervention (DD group) represents a sub-population exposed to a lower risk.

Anyway, Ditter's question "how many of these people (DDs participating in the intervention) are new designated drivers recruited by the program, as opposed to those who would have acted as such even without the program, or would have used other safe transportation alternatives?" remained unanswered. ${ }^{4}$ We speculate that the DDs that took part in our project may already act as a good designated driver even without the intervention, since they have a lower risk profile than the general population and since they reported that they did not reduce their alcohol consumption during the event.

In respect of the impact of the intervention (objective 2), the offer of free entrance does not seem to have succeeded in motivating the club-goers who drive to take part in the initiative. The main reason why DDs took part was their curiosity to assess their BAC. An explanation for this may be that people find it difficult to estimate their own BAC on the basis of their alcohol consumption in a given night and their self-perception of sobriety. ${ }^{3}$ For this reason they might be interested in obtaining feedback from empirical data. Another critical element was that most DDs reported that participation in the initiative didn't change their drinking behavior at all. This may be explained by the prevailing desire to know one's BAC, rather than a commitment to the initiative and an interest in the free entrance incentive. Given the low proportion of DDs that drank less than usual because of the incentive $(5 \%, \mathrm{~N}=6)$, it seems that this incentive has a poor impact on the change in drivers' drinking behavior. It does, however, provide an opportunity for club clients to have their BAC assessed and it may be a good way to involve them in prevention initiatives in this context. The incentive of free entrance does not seem to motivate the drivers to drink less, at least in the specific context of the city of Milan, where admission is often charged, but where it is not difficult to 
la ciudad de Milán, donde la entrada suele cobrarse, pero es fácil obtener descuentos o entradas libres. En el futuro podría haber programas que explorasen otro tipo de incentivos más atrayentes.

Hay dos aspectos destacables. En primer lugar, como en otro estudio, la valoración de la verdadera CAS fue un elemento sólido en esta investigación: constituye un indicador empírico de la verdadera conducta del conductor durante la noche ${ }^{9}$. Lamentablemente, los resultados del presente estudio no se pueden comparar con los resultados de la evaluación de otros programas de conductor designado ensayados previamente, ya que estos últimos se basaban en la eficacia de la intervención para incrementar el número de $C D$ y no tenian en cuenta lo que habian bebido durante la noche $e^{4-7}$.

En segundo lugar, y de acuerdo con la experiencia del personal de campo, hay que tener en cuenta que las intervenciones con conductores designados no consideran el consumo de sustancias psicoactivas, que también afectan negativamente a la capacidad para conducir ${ }^{12}$. Aunque un CD no beba, podría conseguir el incentivo sin problemas a pesar de haber consumido drogas durante la noche. En la intervención "Conductor Seguro", un CD admitió con toda franqueza que había consumido cannabis, pero no alcohol. Obviamente, es un punto débil de este tipo de intervención que sólo valora el consumo de alcohol.

Este estudio ofrece nuevas perspectivas, pero tiene una serie de importantes limitaciones. En primer lugar, carecemos de información sobre los conductores que al entrar en la discoteca aceptaron participar en la intervención del «Conductor Seguro", pero se marcharon sin cubrir el cuestionario y sin someterse al alcoholimetro $(n=105)$. Dada la baja tasa de rechazo, parece lógico asumir que el grupo de conductores que aceptaron participar era más representativo del universo objetivo que el subgrupo de conductores que constituian el grupo experimental (grupo CD). Los conductores que no se reunieron con el personal de campo antes de marcharse seguramente presentaban un perfil de riesgo mayor. No sabemos por qué no lo hicieron, pero el incentivo de la entrada gratis no fue suficientemente atractivo para ellos. Si hubiésemos entregado el cuestionario a los conductores cuando aceptaron participar en la intervención, y no antes de salir de la discoteca, tendriamos datos sobre ellos y una visión mucho más atinada de su perfil de riesgo. Una segunda limitación, común en las evaluaciones de los programas con conductores designados, es que los operadores no valoraron lo ocurrido tras salir de la discoteca: si los CD cumplieron realmente su compromiso de llevar al grupo a casa y se abstuvieron de beber el resto de la noche ${ }^{9}$. Asimismo, los posibles aspectos negativos del programa de conductores designados no se consideraron en este estudio. Algunas críticas han apuntado que los programas de CD: (1) ofrecen una excusa a los pasajeros para consumir más alcohol ${ }^{13}$; (2) presuponen que beber todo lo que se quiera no resulta problemático mientras no se beba y se conduzca, lo cual contribuye a conductas peligrosas como el consumo compulsivo de alcohollit ; (3) centrarse en los actos de los individuos distrae la atención de la gente y de los políticos de los factores obtain discount rates or free entrance. Future programs might explore other types of incentives that may prove to be more attractive.

Two aspects are noteworthy. First, as in another study, the assessment of actual BAC was a solid element in this study: it represents an empirical indicator of the driver's actual behavior during the night. ${ }^{9}$ Unfortunately, the findings of the present study are not comparable with the results of the evaluation of other designated driver programs previously illustrated, as those results were based on the effectiveness of the intervention to increase the number of DDs and didn't consider how much they had drunk during the night. ${ }^{4-7}$

Second, from the field staff's experience, it should be noted that designated driver interventions do not consider at all the use of psychoactive substances, which also may have negative effects on the driver's capacity. ${ }^{12}$ If a DD doesn't drink, s/he could easily get the incentive even if s/he used drugs during the night. In the "Safe driver" intervention, a DD frankly admitted the use of cannabis but not of alcohol. Obviously this is a critical aspect of this kind of intervention because only alcohol consumption is assessed.

While this study provides new insights, some limitations are noteworthy. First, we have no information about drivers who entered the club agreeing to take part in the "Safe driver" intervention, but leaving the club without completing the questionnaire and without being breathalysed $(N=105)$. Given the low refusal rate, it seems reasonable to assume that the overall set of drivers agreeing to take part was more representative of the target population than the subset of drivers constituting the experimental group (DD group). The drivers who did not come back to the field staff before leaving probably had a greater risk profile. We do not know why they did not return, but possibly the free entrance incentive was not attractive enough for them. If we had given the questionnaire to drivers when they agreed to take part in the intervention and not just before they left the club, we could have collected data on those drivers. That would have given much more insight into those drivers' risk profile. A second limitation, common in designated driver program evaluations, is that the operators did not assess what happened after the club, whether the DDs actually followed through on their commitment by driving the group home and by refraining from drinking and driving for the rest of the evening. ${ }^{9}$ Also, the possible negative aspects of the designated driver approach were not considered in this study. Some critics have speculated that DD programs: (1) give an excuse to DDs' passengers to consume more alcohol; ${ }^{13}$ (2) imply that it is not problematic to drink as much as you want as long as you do not drink and drive, contributing to dangerous behavior like binge-drinking: ${ }^{14}$ (3) focusing on the actions of individuals may divert the public's and policymakers' attention from addressing the environmental and social factors that contribute to both alcohol consumption and drink-driving. ${ }^{13,14}$ 
ambientales y sociales que contribuyen al consumo de alcohol y a la conducción bajo los efectos del mismo ${ }^{13,14}$.

En conclusión, la eficacia de la intervención del "Conductor Seguro" no cuenta con un respaldo contundente. El incentivo de la entrada gratis no invita a los conductores a beber menos, lo cual contrasta con la hipótesis de la intervención. Por otro lado, la intervención del "Conductor Seguro" atrae a una subpoblación de bebedores de menor riesgo. Hasta el momento, ningún estudio ha considerado este aspecto. Se necesitan más investigaciones (i) para evaluar la eficacia de las intervenciones con conductor designado en las que se haya eliminado la parcialidad en la selección de conductores, utilizando por ejemplo otros incentivos, y (ii) tener una idea clara del perfil de riesgo de los conductores designados, sobre todo con respecto a la CBEA. Si en el futuro la dinámica de la intervenciones con conductor designado cuenta con el apoyo de pruebas más claras, podría formar parte de ciertos programas como medida específica dirigida a un grupo de conductores de menor riesgo, mientras que los servicios de pasajeros seguros pueden orientarse a grupos de bebedores con un alto riesgo de CBEA ${ }^{11}$.

\section{REFERENCIAS / REFERENCES}

1. World Health Organization. Drinking and driving: a road safety manual for decision-makers and practitioners. Global Road Safety Partnership 2007.

2. ISTAT Istituto Nazionale di Statistica (IT). [Data on traffic accidents in Italy during the year 2006]. 2007. Italian.

3. Fornari L. Drink-driving and perceptions: a field survey in the recreational settings of Milano, Italy. Project UMG. Communication presented at Club Health 2008 conference. Ibiza, Spain, 23rd-25th June 2008.

4. Ditter SM, Elder RW, Shults RA, Sleet DA, Compton R, Nichols $J$ L. Effectiveness of designated driver programs for reducing alcohol-impaired driving. A Systematic Review. Am J Prev Med 2005; 28: 281-87.

5. Boots K. The designated driver program: an outcome evaluation. Health Promot J Austr 1994; 4: 26-9.

6. Brigham $T$, Meier $S$, Goodner V. Increasing designated driving with a program of prompts and incentives. J Appl Behav Anal 1995; 28: 83-94.

7. Meier S, Brigham T, Gilbert B. Analyzing methods for increasing designated driving. J Prev Intervention Community 1998; 17: 1-14.
In conclusion, the effectiveness of the "safe driver" intervention does not seem to be supported by strong evidence. The incentive of free entrance does not motivate drivers to drink less. This is in contrast with the intervention's assumption. Moreover, the "Safe driver" intervention seems to reach a subpopulation of drinkers who are less at risk. So far, no research studies have taken this fact into consideration. More research is needed (i) to evaluate the effectiveness of designated driver interventions where the bias in the selection of drivers has been removed, by, for example, using other incentives and (ii) to have a clear understanding of designated drivers' risk profile, especially as regards DUI. If in the future the dynamics of designated driver interventions is supported by clearer evidence, they might be part of programs as specific measures for a target of less risky drivers, while safe ride services may be used instead for a target of drinkers at high risk for DUI."

8. Winsten J. Promoting designated drivers: the Harvard Alcohol Project. Am J Prev Med 1994; 10: 11-4.

9. Timmerman M, Geller E, Glindemann K, Fournier A. Do the designated drivers of college students stay sober? J Safety Res 2003; 34: 127-33.

10. Campbell DT, Stanley JC. Experimental and quasi-experimental designs for research. Chicago: Rand McNally; 1963.

11. Caudill BD, Harding WM, Moore BA. At-risk drivers use safe ride services to avoid drinking and driving. J Subst Abuse 2000; 11: 149-59.

12. Kelly $E$, Darke $S$, Ross J. A review of drug use and driving: epidemiology, impairment, risk factors and risk perceptions. Drug Alcohol Rev 2004; 23:319-44.

13. Aspler $R_{1}$ Hardin $W_{1}$ Goldfein J. The review and assessment of designated driver programs as an alcohol countermeasure approach, Washington DC: U.S. Department of Transportation, National Highway Traffic Safety Administration 1987.

14. DeJong $W$, Wallack $L$. The role of designated driver programs in the prevention of alcohol-impaired driving: a critical reassessment. Health Educ 0 1992; 19: 429-42. 